\title{
“Apostles and men of learning": Miguel Venegas, Andrés Marcos Burriel, and the Jesuit Vocation for Natural History
}

\author{
Bryan Green \\ Pontificia Universidad Católica de Valparaíso \\ brgreenı@gmail.com
}

\begin{abstract}
The transformation of the Empressas apostólicas (1739), a manuscript history of the Jesuits' missions in Lower California written by the novo-Hispanic Jesuit Miguel Venegas, into the Noticia de la California (1757), a thoroughly revised version of Venegas's original prepared by the Spanish Jesuit Andrés Marcos Burriel, provides a case study in how the enactment of the Jesuit ascetic ideal exercised on the Spanish-American mission frontier was closely linked to Enlightenment natural history and ethnography. Through an analysis of both works, as well as Burriel's correspondence with his Jesuit confrères in New Spain, this article aims to demonstrate the underlying tension in eighteenth-century Jesuit writing between traditional, providential narratives and the skeptical, scientific discourse of secular natural histories. Burriel's work, which was widely translated and disseminated throughout Europe, aimed to bridge these two discourses by employing the Society's apostolic-ascetic vocation and global missionary network in the service of natural histories that would appeal to a secular reading public and inform Spanish colonial administration.
\end{abstract}

\section{Keywords}

California - New Spain - natural history - Enlightenment - Miguel Venegas - Andrés Marcos Burriel - Noticia de la California (1757)

* This article was written with the support of a research grant from the Chilean government (FONDECYT Iniciación en Investigación $\mathrm{N}^{\circ} 11140527,2014-17$, "El ascetismo y el problema de la teodicea en la Hispanoamérica colonial").

(C) GREEN, 2017 | DOI 10.1163/22141332-00401002

This is an open access article distributed under the terms of the Creative Commons Attribution-

Noncommercial 4.0 Unported (CC-BY-NC 4.0) License. http://creativecommons.org/licenses/by-nc/4,0/02:26:30PM 
The letter from Andrés Marcos Burriel (1719-62) to Juan Antonio Balthasar (1697-1763), a former Jesuit provincial of New Spain, ${ }^{1}$ dated July 20,1760 , is perhaps the most extraordinary document in the Spanish polymath's correspondence with his Jesuit confrères in New Spain, as it not only refers to his recently published Noticia de la California y su conquista temporal y espiritual hasta el tiempo presente (1757) and plans for future works on the natural history of Spanish America but also gives a detailed account of the current events in Europe that were about to overwhelm the Society. The occasion for this correspondence was his novo-Hispanic peers' positive reception of the Noticia, which was based on a manuscript history of the Lower California missions written by the Criollo Jesuit Miguel Venegas (1680-1764) almost two decades earlier. $^{2}$ The exchange of letters between the Spanish Jesuit and his senior

1 A native of Lucerne, Switzerland, Balthasar arrived in New Spain in 1719 and served as provincial from $175^{\circ}$ to 1753 . He was the author of several edifying letters on Jesuit missionaries from the province. Though he was born Jean Antoine Balthasar, as he appears in Carlos Sommervogel's bio-bibliography, his works in Spanish were signed with the hispanicized version of his name, which his Spanish and novo-Hispanic peers likewise used to address him. Interestingly, he signed his letters with an abbreviation of his given name that allowed for both uses. José Gutiérrez Casillas, Diccionario bio-bibliográfico de la Compañía de Jesús en México, vol. 25 (México, D.F.: Editorial Tradición, 1977), 227-69.

2 The Jesuit regime in Lower California, the peninsula occupied today by the Mexican states of Baja California Norte and Baja California Sur, began with the founding of the first permanent missions by Juan María Salvatierra (1648-1715) and José María Piccolo (1654-1729) in 1697 and ended with the expulsion of the last missionaries from Spanish territories in 1768. Though the Jesuits explored as far north as the Colorado River delta, the northernmost Jesuit mission was founded in 1767 , approximately three hundred miles south of the current Mexico-United States border. The missions depended partly on funding from the treasury of the viceroyalty, but they existed outside the political jurisdiction of New Spain, and the Jesuit missionaries exercised considerable autonomy over ecclesiastical and secular affairs. Unlike their confrères in Paraguay, to which they were sometimes compared during the eighteenth century, the California Jesuits were accompanied by a sizeable contingent of soldiers and colonists. Although conflicts often emerged between the missionaries and soldiers, the latter were viewed as a necessary evil in order to insure the safety and permanence of the missions. The Mexican historian Ignacio del Río has thus referred to the Jesuit occupation of California as a "missionary-military conquest." Conquista y aculturación en la California jesuítica, 1697-1768 (México, D.F.: Universidad Nacional Autónoma de México, 1998), 95. While the Jesuits' autonomy was cited as a reason for their expulsion, the system they established was repeated by the Franciscans, who took over the California missions after 1768 and extended their reach into the province of Upper California, today part of the United States. The difficulty of sending resources, colonists, and troops to such far-flung regions made this the only practical solution to establishing Spanish sovereignty over regions that had begun to attract other European empires. As the Franciscans shifted their efforts to the founding 
confrère, who anxiously awaited news from Europe on the tribulations of the Society, amounts to an intimate and unique snapshot from the trenches of the theological, philosophical, and political battles engulfing the Society of Jesus at the time.

Explaining his plans for a revised edition of the Noticia, Burriel advocates for the adaptation of Jesuit writing to an evolving European public sphere, assuring Balthasar of the need to produce work that "would please the taste of Europe" and thus assure an ample readership. ${ }^{3}$ Aware of the Society's precarious reputation in Enlightened Europe, Burriel viewed the production of natural histories as a means of defending the order against its detractors. Nevertheless, for Burriel this also implied a return to the tradition of Jesuit natural historians such as José de Acosta (1540-1600), whose Historia natural y moral de las Indias (1590) continued to be praised even in the eighteenth century. ${ }^{4}$ This example, asserts Burriel, should serve as an admonition to the contemporary Jesuits of Spanish America whose lack of interest in producing "methodical, inquisitive and orderly relations together with maps, drawings and political discourses" had occasioned grave errors in the administration of the Americas. ${ }^{5}$

According to the Spaniard, the most serious consequence of the diminished initiative to produce reliable information from the Jesuit missions was the expulsion of the order from all Portuguese territories in $175^{8}$, which according to Burriel was the result of misinformation about the order's activities in the Americas. Though Burriel also criticizes the character of his compatriots who show little interest for matters far from the metropole, he asserts that the Society would continue to bear the brunt of the consequences if they failed to

of missions in the more attractive lands of Upper California, the peninsular missions were transferred in 1773 to the Dominican order, in whose hands they would remain until the midnineteenth century. Ignacio del Río and María Eugenia Altable Fernández, Breve historia de Baja California Sur (México D.F.: Fondo de Cultura Económica, 200o); Salvador Bernabéu Albert, Expulsados del infierno: El exilio de los misioneros jesuitas de la península californiana (1767-1768) (Madrid: Consejo Superior de Investigaciones Científicas, 2008); David J. Weber, Bárbaros: Spaniards and Their Savages in the Age of Enlightenment (New Haven: Yale University Press, 2005), 120-26.

3 "[...] alhagar el gusto de Europa." Andrés Marcos Burriel to Juan Antonio Balthasar, July 20, 1760 (Huntington Library, Pasadena CA, HM 22245), 1.

4 Fermín del Pino Díaz, "Introduction," in José de Acosta, Historia natural y moral de las Indias (Madrid: Consejo Superior de Investigaciones Científicas, 2008), xvii-lii, here xxviii.

5 "Por falta de relaciones methodicas, curiosas, y ordenadas en un cuerpo con Mapas, dibujos, y discursos politicos vía en nuestra Corte profunda ignorancia de el estado, tierras, ríos, comercio, entradas, salidas, etc. de la América meridional." Letter to Balthasar, July 20, 1760 (Huntington Library, Pasadena CA, HM 22245), 2. 
publish works aiding the political and economic administration of the colonies: "but if the Jesuits do not do this, nobody will, and they will ultimately pay the price." ${ }^{6}$ Burriel's letter to Balthasar goes on to describe the embattled position of the Society in both the European Republic of Letters as well as in the political sphere. According to the Spanish Jesuit, the declining fortunes of his order had affected him personally as they had led to his removal as director of the ecclesiastical archives in Toledo. ${ }^{7}$ In his letter, Burriel outlines four interrelated fronts on which the Jesuits faced fierce opposition: Paraguay, Portugal, French Jansenism, and the theological dispute with Daniello Concina, a Dominican friar who published a theological treatise in 1749 that condemned Jesuit Molinism and probabilism and which, according to Burriel, was compendium of anti-Jesuit calumnies "scattered about for more than a century and a half in a thousand libels and books." 8 Burriel asserted that the most efficacious response to these attacks was the conscientious exercise of the Jesuits' dual vocation as apostles and producers of historic and scientific knowledge: "Our life, to what does it call us?" asks the Spaniard, "What is our profession if not that of apostles and men of learning?"9

This article will examine Burriel's transformation of Venegas's sprawling, providentialist account of the Lower California missions as indicative of an underlying tension in eighteenth-century Jesuit historiography between traditional hagiographic accounts of the mission frontier and the use of Jesuit resources for the production of natural histories that would appeal to a broad, secular reading public in Europe and the Americas. Despite the radical differences between Venegas's manuscript and Burriel's final version of the Noticia, they share an underlying methodology that depended on the Society's worldwide network of missions and the apostolic-ascetic vocation embodied by the Jesuit missionary on the Spanish-American colonial frontier. Burriel's correspondence regarding the Noticia furthermore demonstrates that contemporary

6 “...] pero si los Jesuitas no lo hacen, nadie lo ha de hacer, y ellos pagan la pena de que no se haga." Ibid.

7 On his removal as director of the monumental project of a complete ecclesiastical history of Spain in 1754, see Alfonso Echánove Tuero, La preparación intelectual del P. Andrés Marcos Burriel, S.J. (Madrid: Instituto Enrique Flórez-Consejo de Investigaciones Científicas, 1971), 126-29.

8 "[...] no ha echo otra cosa, que juntar en sus libros todas las calumnias contra la Compañía sobre theología moral, esparcidas por mas de un siglo en mil libros y libelos." Andrés Marcos Burriel to Juan Antonio Balthasar, July 20, 1760 (Huntington Library, Pasadena CA, HM 22245), 4.

9 "Nuestra vida a qué llama? Nuestra profesión qual es, sino de Apostoles y hombres doctos?" Ibid., 15 . 
Jesuits were keenly aware of the Society's past contributions and future potential as producers of natural histories, and to this end sought to adapt the order's missionary enterprise to the demands of a secular Enlightenment reading public avid for such works. This correspondence also reveals that Jesuits on both sides of the Atlantic were also deeply concerned with the increasing cultural and political backlash against the order in Europe, and viewed works such as the Noticia as a means to quell criticism and prove the usefulness of the Society of Jesus to the Spanish state and to the general improvement of knowledge.

\section{Global Networks, Ascetic Discipline, and Jesuit Natural History}

Studies of eighteenth-century Spanish and Spanish-American natural history have traditionally focused on the querelle de l'Amérique, which pitted European naturalists and historians who affirmed the degenerate nature of the Americas against Criollo authors who defended not only the variety and fertility of the New World but also the epistemological foundations of knowledge produced from the Americas. ${ }^{10}$ The most prominent of these Criollo authors were Jesuits such as Francisco Javier Clavijero (1731-87), who responded to European historians from exile in the Papal States following their expulsion from Spanish territories in $1767 \cdot{ }^{11}$ Jorge Cañizares-Esguerra maintains that eighteenth-century

10 Gerbi, Antonello, The Dispute of the New World: The History of a Polemic, 1750-19oo, trans. Jeremy Moyle (Pittsburgh: University of Pittsburgh Press, 1973), 187-233.

11 Though more widely recognized for his Historia antigua de México (translated and published in Italian in 1780), Clavijero also published a supplement to Burriel's Noticia that was based on information gathered directly from exiled Jesuit missionaries who had lived in Lower California. Though David Brading recognizes that Clavijero belonged to a generation of novo-Hispanic Jesuits that sought to incorporate Enlightenment science, history, and philosophy into their work, he nevertheless focuses on the Jesuit historian's contribution to a Criollo identity that broke from seventeenth-century baroque aesthetics. Likewise, Antony Higgins emphasizes Criollo Jesuits' reaction to increasingly onerous economic and political reforms in the second half of the eighteenth century. Constructing the Criollo Archive: Subjects of Knowledge in the Bibliotheca mexicana and the Rusticatio mexicana (West Lafayette, IN: Purdue University Press, 2000). Higgins argues that the Jesuit colleges acted as a "stand in for the absent public sphere" among the Criollo elite and promoted the values of Europe's secular Enlightenment: "in particular, empiricism, experimental method, an aesthetics based on clarity of exposition and universal standards of 'good taste,' and a pragmatic approach to agriculture and economy" (16). Miguel LeónPortilla, "Introducción a la Historia de la Antigua o Baja California de Francisco Xavier Clavijero," in Francisco Xavier Clavijero, Historia de la antigua California (México: Porrúa, 1990), ix-xli; David Brading, Orbe indiano: De la monarquía católica a la república criolla, 
Criollo and Spanish natural history developed a "patriotic epistemology" that contested and critiqued the conjectural Enlightenment histories of Spain and Spanish America written from London, Paris, and Berlin. ${ }^{12}$ While Jesuits were important contributors to these polemics, the origin of the Society's contributions to eighteenth-century natural history, as the story of the Noticia demonstrates, is to be found in the order's apostolic network and ascetic vocation applied to the production of knowledge on the nature and peoples they encountered on the colonial frontier, and less so as the result of a reactive, patriotic epistemology.

The inclusion of the Society of Jesus in the history of Enlightenment science has occurred within a general shift of focus away from Enlightenment thought as a set of fixed principles toward the study of the discourses and practices involved in gathering, distributing, and applying knowledge, particularly in the fields of geography, natural history, and ethnography. ${ }^{13}$ As Mordechai Feingold asserts, this inclusion requires abandoning the negative stereotypes of the Jesuits' relation to modern philosophy and science that have prevailed since the eighteenth century. Feingold demonstrates that though Jesuits with the talent and propensity for scientific pursuits could face resistance from their superiors within the Society, they nevertheless found ways to participate in the circulation of new ideas beyond the apostolic aims of the order. ${ }^{14}$ As viewed through his correspondence with fellow Jesuits and his revision of Venegas's manuscript, Burriel exemplifies this balancing act between an individual interest in the current state of science and the institutional aims of the Society.

Studies of the Jesuit's role in the history of science have likewise focused on the order's worldwide network of missions and colleges as a conduit for the circulation of knowledge about the natural world. Building on John Law and Bruno Latour's work in actor-network theory, Stephen Harris has demonstrated

1492-1867, trans. Juan José Utrilla (México: Fondo de Cultura Económica, 1991), 486-98. Anthony Pagden, "From Noble Savages to Savage Nobles: The Criollo Uses of the Amerindian Past," in Pagden, Spanish Imperialism and the Political Imagination (New Haven: Yale University Press, 1990), 97-116.

12 Cañizares-Esguerra writes, "In the discourse of patriotic epistemology, the foreign observer appeared as the nemesis of the learned clerical witness." Jorge Cañizares-Esguerra, How to Write the History of the New World: Histories, Epistemologies, and Identities in the Eighteenth-Century Atlantic World (Stanford: Stanford University Press, 2001), 204-10.

13 David N. Livingstone and Charles W.J. Withers, "Introduction: On Geography and Enlightenment," in Geography and Enlightenment, ed. David N. Livingstone and Charles W.J. Withers (Chicago: University of Chicago Press, 1999), 1-26.

14 Mordechai Feingold, "Jesuits: Savants," in Jesuit Science and the Republic of Letters, ed. Mordechai Feingold (Cambridge: The MIT Press, 2003), 1-45. 
that the Society of Jesus functioned as one of the early modern period's most important corporate organizations for the collection, concentration, and dissemination of knowledge about nature. Harris argues that the Jesuits were principal contributors to the "large-scale sciences," such as astronomy, geography, natural history, meteorology, and navigation, which required many contributors working within a tightly organized network stretching across the globe. ${ }^{15}$ The Jesuits' success is attributed not only to their ability to collect data from their global missions and then disseminate findings among learned circles in the metropole, but also their ability to use the same circulation of information to instill discipline and morale in members who saw their contributions to the study of nature as a necessary complement to their apostolic mission. ${ }^{16}$ As Paula Findlen observes, the development of natural history in early modern Europe up to the eighteenth century is lacking in the type of "Copernican revolution" that marked other natural sciences in the sixteenth and seventeenth centuries, but rather developed slowly through information sharing media and networks in early modern Europe.${ }^{17} \mathrm{~A}$ discipline that developed among a disparate group of practitioners, natural history involved the observation, description, collection, and classification of flora, fauna, and minerals as well as ethnographic accounts of the cultures encountered in the expansion of European empires in the sixteenth and seventeenth centuries. What came to fruition in the eighteenth century was the accumulated experience of early modern naturalists and scientific travellers, among whom the Jesuits played a prominent role.

Approaching the history of early modern science from the perspective of gender studies, Dušan I. Bjelić notes that the Jesuits' particular vocation and international reach lent itself to experimental science, in which homosocial ties were forged through the ascetic discipline required for rigorous and

15 Stephen Harris, "Confession-Building, Long-Distance Networks, and the Organization of Jesuit Science," Early Science and Medicine 1 (1996): 287-318, here 311.

16 Harris, ibid. In his study of the early missions in Peru, Paraguay, and Chile, Andrés Prieto argues that Jesuit science also emerged from the practical needs of evangelization, and the missions themselves became important contact zones for the collaborative acquisition and application of linguistic, botanical, and medicinal information. Andrés Prieto, Missionary Scientists: Jesuit Science in Spanish South America (Nashville: Vanderbilt University Press, 2011), 29-35.

17 Paula Findlen, "Natural History" in The Cambridge History of Science, vol. 3, ed. Katherine Park and Lorraine Daston (Cambridge: Cambridge University Press, 2006), 435-69, here 436 . 
precise scientific work..$^{18}$ According to Bjelić, the hyper-masculine, ascetic culture implicit in this type of experimental science was premised on the absolute exclusion of the feminine, which was associated with desire and error.

Cañizares-Esguerra likewise recognizes the "ascetic behavior and forms of self-restraint” implicit in eighteenth-century historians' and naturalists' search for objective truth in the Americas. ${ }^{19}$ Just as with the Jesuit's corporate identity, the enlightened researcher opposed his masculine, celibate discipline to effeminate, subjective distortions of truth. Mary Louise Pratt also observes this masculine ascetic ideal in Linnaeus's eighteenth-century revolution of natural history, which was based on a worldwide network of fieldworkers that was in many ways similar to the Jesuit missionary network. ${ }^{20}$ According to Pratt, the "innocent" gaze of eighteenth-century secular travel writing obscured the history and consequences of European imperialism by focusing on natural and ethnographic description. What Pratt defines as the discourse of "anti-conquest" was already employed in Jesuit histories in which the diachronic narrative of "peaceful" or "spiritual conquest," with all its inherent contradictions, was gradually detached from a synchronic, synoptic description of the geography, flora, fauna, and peoples encountered in the missionary enterprise. ${ }^{21}$

As Florence Hsia has demonstrated in her study of China Jesuits, the view of the Society as a key early modern network through which texts and objects

18 Dušan I. Bjelić, Galileo's Pendulum: Science, Sexuality and the Body-Instrument Link (Albany: State University of New York, 2003), 59-75.

19 Cañizares-Esguerra, How to Write, $5^{2}$.

20 Mary Louise Pratt, Imperial Eyes: Travel Writing and Transculturation (New York: Routledge, 1992), 56-57.

21 In Historia de los triumphos de nuestra santa fee (1645), a history of the first Jesuit missions in the northwest of New Spain, Andrés Pérez de Ribas refers to the order's undertaking as a "conquista espiritual" modeled after the Acts of the Apostles. This same definition was used to describe the Jesuits' undertaking in Lower California, as in Francisco Zevallos' "Carta edificante" on Fernando Consag, who served as a missionary in the peninsula: "Ganar así los corazones de los hombres, es un género de Conquistas, que hace un misionero desarmado, y no puede hacer todo el estruendo, y terror de las armas. Tanto más poderosas son las armas del zelo, mansedumbre, y caridad cristiana, que son las con que se fundó, y se propaga el Imperio de Jesu-Cristo." This discourse, however, belies the reality of the California missions, as they were founded through what Ignacio del Río calls a "missionary-military conquest." Andrés Pérez de Ribas, Historia de los triunphos de nuestra santa fee, ed. Ignacio Guzmán Betancourt (México: Siglo XXI, 1992), xv; Francisco Zevallos, Carta del Padre Provincial Francisco Zevallos sobre la apostólica vida y virtudes del P. Fernando Konsag, insigne misionero de la California (México: Colegio de San Ildefonso, 1764), 13; Del Río, Conquista y aculturación, 95. 
circulated across the globe must be complemented with a view to how the actors involved in this network understood and articulated their vocation through diverse genres. ${ }^{22}$ Though there are many striking parallels between the French Jesuits studied by Hsia and the Spanish Jesuit Burriel, who similarly compiled and edited his confrères' reports from the mission field in an effort to link to the order's global network to European scientific institutions, there is nonetheless a fundamental difference between the Jesuit as missionaryscientist in China and his counterpart in Spanish America. While, as Hsia demonstrates, French missionaries felt their work could only be conducted successfully in China's urban centers with access to sophisticated equipment and updated scientific works, Burriel and his interlocutors in New Spain linked the production of natural history to the outermost mission frontier, where the Jesuit would act as a field researcher in pursuit of geographic, ethnographic, zoological, and botanical data. ${ }^{23}$ In this sense, the apostolic-ascetic ideal represented in the order's hagiographical works, in which the model Jesuit missionary is portrayed as a self-sacrificing apostle who tests his virtue against the moral and physical dangers of the frontier, naturally fused with the vocation of the Jesuit as fieldworker, who would likewise face the same perils not only ad maiorem Dei gloriam but also in the advancement of science. ${ }^{24}$

This research into Jesuits' scientific pursuits within a global framework coincides with new approaches to mission history, which seek a more nuanced understanding of the complex interactions between Europeans and Amerindians on the frontiers of colonial Spanish America. ${ }^{25}$ These approaches inevitably

22 Florence Hsia, Jesuits and Their Scientific Missions in Late Imperial China (Chicago: The University of Chicago Press, 2009), 6-12.

23 Ibid., 122

24 It is worth noting that throughout the seventeenth century Jesuit historians in Spanish America often explicitly compared the self-denial and ascetic discipline required for mission work in the Americas to the relative comfort of their brethren in the Asian missions. Antonio Ruiz de Montoya, Conquista espiritual hecha por los religiosos de la Compañía de Jesús en las provincias del Paraguay, Paraná, Uruguay y Tapé (Madrid: Imprenta del Reino, 1639), $62^{\mathrm{v}}$ (a new annotated English translation of this work is forthcoming in 2017 from the Institute of Jesuit Sources at Boston College); Pérez de Ribas, Historia de los triunphos, 408-9.

25 In contrast to the school of Borderlands History founded by Herbert Eugene Bolton, David Sweet describes the new mission history: "Nothing about the mission enterprise is self-evident, and in view of its terrible consequences for the native populations it was designed in principle to benefit, nothing about it should any longer be taken for granted or at face value by serious historians." David Sweet, "The Ibero-American Frontier in Native American History," in The New Latin American Missionary History, ed. Erick Langer and Robert H. Jackson (Lincoln, NE: University of Nebraska Press, 1995), 1-48, here 45. 
face the paradox of Jesuit writing on the colonial frontier: while constituting a massive, invaluable archive of information on Amerindian cultures from the colonial period, it is also colored by deep national and religious biases. In a literature review of recent scholarship on the Jesuit missions on the northwest frontier of New Spain, Salvador Bernabéu perceives the reproduction of a "theocratic and triumphalist" discourse even among contemporary secular historians, and he calls upon his peers to engage in a more critical reading of Jesuit writing within the context of colonial history. ${ }^{26}$ In the same vein, Ivonne del Valle describes the Jesuit missions of New Spain as a space of intense cultural exchange in which the missionaries' monological culture was threatened by the centrifugal forces of Amerindian resistance. ${ }^{27}$ In the case of Lower California, del Valle argues that the failure to convert the natives and establish self-sustaining missions led to a focus on ethnography, botany, and geography, which allowed the Jesuits to assert their dominion from afar. ${ }^{28}$ Similarly, Kristin Huffine reads eighteenth-century Jesuit natural histories on Paraguay as a means of justifying Amerindian dependency on the order's mission system within the epistemological framework of Enlightenment natural science. ${ }^{29}$ Burriel's transformation of Venegas's manuscript and his correspondence with his novo-Hispanic counterparts provide further insight into how the Jesuit vocation as "apostles and men of learning" adapted to both local contingencies on the mission frontier and to the global, secular perspective of Enlightenment natural history.

\section{Miguel Venegas's Empressas apostólicas: Providential History and "Mappas historiales"}

Given that he dedicated a great deal of his life's work to documenting the lives of his confrères in the province of New Spain, there is some irony in the

26 Salvador Bernabéu, "La invención del Gran Norte ignaciano: La historiografía sobre la Compañía de Jesús entre dos centenarios (1992-2006)," in El Gran Norte mexicano: Indios, misioneros y pobladores entre el mito y la historia, ed. Salvador Bernabéu (Sevilla: Consejo Superior de Investigaciones Científicas, 2009), 165-211, here 171.

27 Ivonne del Valle, Escribiendo desde los márgenes: Colonialismo y jesuitas en el siglo XVIII (Mexico: Siglo XXI, 2009), 77 .

28 Ibid., 189.

29 Kristin Huffine, "Raising Paraguay from Decline: Memory, Ethnography, and Natural History in the Eighteenth-Century Accounts of the Jesuit Fathers," in El saber de los jesuitas, historias naturales y el nuevo mundo, ed. Domingo Ledezma and Luis Millones Figueroa (Madrid: Vervuert-Iberoamericana, 2005), 279-302, here 282. 
paucity of biographical information on Miguel Venegas. In his early nineteenthcentury bibliography of New Spain, José Mariano Beristáin y Souza (1756-1817) writes that the Jesuit chronicler was born in 1680 in Puebla de los Angeles, and that after entering the order in 1700 he worked as a professor in the Colegio Máximo de San Pedro y San Pablo in Mexico City, occupying the chair in moral theology of the same institution in 1714. Ten years later, Venegas retired from his post due to ill health resulting from a pair of incorrectly prescribed bleedings and, according to Beristáin y Souza, "withdrawn from the bustle of the city he lived 40 years in the countryside, dedicated entirely to writing." ${ }^{30}$ Although the Mexican bibliographer notes that he took his information from a vida written by Salvador de la Gándara (1697-1773), the work has yet to turn up in the libraries and archives of Latin America or Europe. ${ }^{31}$

While the loss of the Vida of Venegas has deprived us of another example of the genre of eighteenth-century Jesuit hagiography, along with valuable details concerning one of the most active Jesuit historians of eighteenth-century New Spain, the prolific bibliography provided by Beristáin y Souza gives us important insight into Venegas's literary production. A perusal of the titles attributed to Venegas, though many have been lost, tells us a great deal about the Jesuit historian and the literary milieu of New Spain during the first half of the eighteenth century. Venegas not only wrote missionary hagiographies and chronicles of his order's apostolic mission, but also penned hierophantic works dedicated to the Virgin Mary, several Latin hymnals, guides for missionaries and parish priests, selections from classical authors, and devotional poetry. During Venegas's lifetime, three of his historical-hagiographic works were published after undergoing thorough revisions at the hands of fellow Jesuits: Vida y virtudes del V.P. Juan Baptista Zappa, reworked by the Catalan Francisco Javier Fluviá (1699-1783) and published in Barcelona in 1754; El apóstol mariano representado en la vida del V.P. Juan María Salvatierra, revised by Juan Antonio de Oviedo (1670-1757) and published in México in 1754; and Burriel's edition of his Empressas apostólicas, published as the Noticia de la California y de su conquista temporal y espiritual hasta el tiempo presente

30 "[...] retirado del bullicio de las ciudades vivió 40 años en el campo, dedicado todo a escribir." José Mariano Beristáin y Souza, Biblioteca hispano-americano septentrional (México, D.F.: Ediciones Fuente Cultural, 1883), 3:261.

31 Gándara was named provincial of the order just prior to the expulsion. His work on Venegas is from 1765. Gutiérrez-Casillas, Diccionario Bio-bibliográfico, 646-47; Michael Mathes, Historical-Biographical Introduction: Obras Californianas del Padre Miguel Venegas, S.J. (La Paz, Baja California Sur: Universidad Autónoma de Baja California, 1978), 6. 
(1757) in Madrid. ${ }^{32}$ In his prologue to the El apóstol mariano, Oviedo tactfully explains that the Jesuit provincial at the time, none other than Father Juan Antonio Balthasar, was forced to commission an abridgement of Venegas's "beautiful and erudite" work in order avoid excessive printing costs. ${ }^{33}$ Despite this show of deference, Balthasar's effusive praise for Burriel's Noticia in letters to the younger Spanish Jesuit suggest that many of his contemporary coreligious found Venegas's work fundamentally flawed due to its lack of appeal to a secular readership.

From the scant biographical details surviving from Gándara's Vida and the prodigious corpus of manuscripts that Beristáin y Souza documented in the archives of early nineteenth-century Mexico, a profile of Venegas emerges as a Jesuit who embodied the vocation of a contemplative in action through scholarly pursuits related to the mission field. The authorship of catechetical guides and hagiographies, sources of both practical knowledge and inspiration for work in the mission field, could serve as a proxy for the ascetic self-sacrifice of the missionary frontier, as many works from the corpus of eighteenth-century Jesuit histories from New Spain attest. ${ }^{34}$ Beyond Venegas's emphasis on the minutiae of his confrères' ascetic trials on the mission frontier, an examination of the Empressas' 700 pages of miniscule and painstaking script divided into 2,047 numbered paragraphs with copious glosses from the Bible and the patristic tradition, reveals to what degree the authorship of the work was itself a sustained exercise of self-discipline.

32 The original full title of Venegas's manuscript is Empressas apostólicas de los padres misioneros de la Compañía de Jesús, de la provincia de Nueva España obradas en la conquista de Californias debida y consagradas al patrocinio de Maria santissima, conquistadora de nuevas gentes en su sagrada imagen de Loreto.

“[...] comenzó, y concluyó hermosa, y eruditamente la vida; pero le salió tan defusa, que atendiendo el P. Juan Antonio Balthazar actual Provincial de esta Provincia, que por lo mucho, que en estas partes cuestan las imprentas de los libros, no podía darse a la luz pública, sin excessivos gastos, me ordenó, que sin faltar a lo substancial de la historia, la reduxesse a compendio más breve." Miguel Venegas, El apóstol mariano representado en la vida del V.P. Juan María de Salvatierra, ed. Juan Antonio de Oviedo (México: Imprenta de Doña María Ribera, Impressora del Nuevo Rezado, 1754), vi.

34 As in Gándara's lost work on Venegas, authors of sacred biographies and devotional works who rarely ventured into the missionary field could become the subjects of hagiographies eulogizing their ascetic virtues. Another such prominent example is Juan Francisco López's (1699-1783) Carta de edificación (1758) on José María de Genovese (1691-1757), the author of several devotional guides under the pseudonym Ignacio Thomay. 
The Empressas furthermore displays a credulity towards the supernatural that was already abating by the end of the seventeenth century. ${ }^{35}$ The clearest example of Venegas's view of the history of California as a providential struggle between the forces of God and Satan is found in his description of the "hechiceros," or shamans, against whom the missionaries struggled in the acculturation of their catechumens. While admitting that some of the "hechiceros" were indeed mere charlatans, Venegas, in stark contrast to Burriel's later skepticism on this topic, suggests that some shamans dealt directly with Satan and acted as his agents in the perdition of the californios. ${ }^{36}$ While Venegas's text maintains throughout a belief in the direct intervention of God and demons in the natural world, his work likewise reflects the transition from the belief in explicit pacts with tangible demons to the internalization of demonic influence through psychological suggestion that was typical of eighteenthcentury historiography in New Spain. ${ }^{37}$ Venegas maintained that even when the californios' shamans did not have direct dealings with demons, the devil perverted them through more subtle means: "but the devil used all means: explicit pacts with the true shamans [hechiceros]; and internal suggestion with the charlatans in order to deceive and pervert these peoples into submitting to his dominion."38

Despite the providential narrative of Venegas's work, his search for source material was exhaustive, though Burriel and others would later complain that

35 According to Jonathan Israel, the "death of the devil," or the widespread skepticism towards witchcraft and demons, is one of the cornerstones of the early Enlightenment that spread through all languages and confessions during the early eighteenth century. Though many Catholic intellectuals were resistant to the Radical Enlightenment's outright rejection of the devil and magic, they nevertheless admitted that popular superstitions exaggerated the frequency and potency of demonic interventions. Jonathan Israel, Radical Enlightenment: Philosophy and the Making of Modernity, 1650-1750 (Oxford: Oxford University Press, 2002), 402-3.

36 In both Burriel's revisions to the Empressas and in Francisco Javier Clavijero's Historia de la Antigua o Baja California (1783), a supplement to the Noticia written from the novo-Hispanic Jesuit's exile in Bolognia, direct pacts between the devil and hechiceros are disdainfully discredited "because in virtue of the reports given by the more capable missionaries, it is known that they had no commerce with the devil." Miguel Venegas, Empressas apostólicas, 543-44; Francisco Javier Clavijero, Historia de la Antigua o Baja California, ed. Miguel León-Portilla (México, D.F.: Porrúa, 1970), 66-67.

37 Fernando Cervantes, The Devil in the New World: The Impact of Diabolism in New Spain (New Haven: Yale University Press, 1994), 97.

38 " [...] mas el demonio de todos se valía: de los hechizeros verdaderos con pacto expresso: $\mathrm{y}$ de los falsos con internas suggestiones, para engañar, y pervertir por su medio à los pueblos trayendolos sugetos à su obdediencia." Venegas, Empressas, 544. 
it lacked a corresponding process of appraisal. Michael Mathes has praised Venegas as employing "the highest level of scientific historical methodology" in his rigorous use of primary sources culled from the Society's archives or requested directly from missionaries working in the field. ${ }^{39}$ As Venegas writes in his prologue to the Empressas, when he could not find the information he needed in the documents provided to him by his superiors, he actively sought reports directly from missionaries in Lower California. ${ }^{40}$ Venegas's comments provide a unique insight into how information circulated throughout the Jesuit network: reports not only flowed from the periphery to the nodal points in order to be uncritically synthesized and aggregated, but also flowed back out to be perfected, completed or amended. Furthermore, Venegas's work demonstrates that this flow of information was not strictly hierarchical, moving from the outer branches to the centers of political power (Mexico City, Madrid, Rome), but could also connect agents horizontally, as for example the missionaries from California who responded to Venegas's queries, sent from the rural outpost of Chicomocelo. ${ }^{41}$

The Empressas possess another surprisingly modern aspect that would likewise influence the organization of Burriel's work: in his dedication to the Marqués de Villapuente, a benefactor of the Jesuit missions, Venegas refers to his work as a "mappa historial," or "historical map." ${ }^{\text {"2 }}$ In the last section of the work, Venegas further develops the concept of the "mappa historial" to include not only the diachronic series of events in the "spiritual conquest" of California, but also a synchronic description of the nature and inhabitants of the peninsula. The following passage demonstrates how Venegas envisaged these two types of "mappas":

We have already covered the terrain of the Californias following the steps of the missionary fathers in their triumph as apostolic conquistadors of those uncultured and barbarous nations, happily subjecting them to the dominion of Jesus Christ, and the fraternity of the holy church. It is now time to lower the sails of our historical discourse, pause and stop to

39 Mathes, Historical-Biographical Introduction, 8.

$40 \quad$ Venegas, Empressas, xxvi-xxviii.

41 Luke Clossey demonstrates that this was a characteristic of the Jesuit information network at both the regional and global level. Clossey describes the trans-pacific exchange of information between China and New Spain as well as circulation within a single region. Salvation and Globalization in the Early Jesuit Missions (New York: Cambridge University Press, 2008), 202-6.

42 Venegas, Empressas, xv. 
contemplate, as if summarized in an historical map, all that the attentive speculation of those evangelical conquistadors observed at distinct times and places with regard to the lands of the Californias, and their inhabitants, thus imitating those temporal conquistadors who first occupy and subdue the inhabitants of new kingdoms and then observe the territory in order to populate it. We will achieve this by proposing here a historical map of the Californias, which is divided into three parts for greater clarity. The first contains the natural description of the land, plants, birds, fish and animals. The second part will depict the customs of the inhabitants when they lived as pagans. The third part will show the Christian government that they now have after their reduction to the faith. ${ }^{43}$

With a rhetorical flourish, Venegas explicitly marks the shift from the diachronic discourse of the apostolic campaign to a synchronic description of the peninsula, even noting the temporal interruption ("pausa") of the discourse as he transitions to the panoptic display of the peninsula's natural history ${ }^{44}$ Furthermore, Venegas compares this method of surveying a territory and its inhabitants to a military strategy, albeit employed by "conquistadores

43 "Hemos corrido ya por toda la tierra de Californias siguiendo con las [sic] narracion los passos, que han dado en su conquista los Padres Missioneros, como Conquistadores Apostolicos de aquellas incultas, y barbaras naciones: para sugetarlas felizmente al imperio de Jesu-Christo, ê introducirlas al gremio dela Santa Iglesia. Tiempo es ya, deque recogiendo las velas al discurso histórico, hagamos pausa, y nos detengamos â contemplar abbreviado como en un mappa historial todo quanto observó dividido, y separado en diversos tiempos, y lugares la attenta especulación de aquellos Conquistadores Evangélicos acerca delas tierras de Californias, y de sus moradores: imittando en esto â los Conquistadores terrenos, que primero se ocupan, en avasallar â los habitadores de nuevos reynos; y después en observar la tierrra, para poblarla. Esto conseguiremos, con proponer aqui un mappa historial delas Californias: el qual para mayor claridad ira dividido en tres partes. La primera contendrá la descripción dela tierra enlo natural con todo lo tocante à sus plantas, aves, pezes, y animales. La segunda representará la tierra en lo moral de sus habitadores, según vivîan en el tiempo de su gentilidad. La tercera darà à veer las Californias, segun el gobierno christiano, que ahora tienen, despues de su reducción â la fê." Ibid., 458 . According to Antonio Rubial García, the Dominican friar Francisco de Burgoa (1605-81) was the first to use this diachronic-synchronic separation in his works on the Dominican province of Oaxaca, Palestra historial (1670) and Geográfica descripción (1674). Nevertheless, Burgoa's "geographic" work is more focused on his order's convents and buildings, and less so on a natural and ethnographic description of the territory. Antonio Rubial García, El paraíso de los elegidos: Una lectura de la historia cultural de Nueva España (1521-1804) (México, D.F.: Fondo de Cultura Económica, 2010), 270. 
evangélicos," thus emphasizing the imperial expansion with which the text is complicit.

Despite the affinity of these "mappas historiales" with modern anthropology, Venegas's work was principally concerned with justifying the endeavors of his fellow Jesuits as part of a providential plan to bring the californios into the fold of Christianity; in other words, he focuses on the discursive and diachronic aspect of his historical map. While Venegas reserved this shift from the discursive and historic to the visual and synchronic for the concluding chapters of his work, and thus subordinated the discourse of natural history to the providential discourse of the Jesuit campaign of reducción, Burriel would reverse this emphasis in his Noticia. Although this shift reflects a general trend in early anthropology to elide colonial relations by presenting an ahistorical account of non-Western cultures through maps, diagrams, and tables, it is also indicative of the influence of the Jesuit ascetic ideal on the discourse of natural history. ${ }^{45}$ Just as with the Jesuit missionary, the authority of the scrutinizing and all-encompassing gaze of the eighteenth-century naturalist was premised on a chaste and self-possessed subject who risked the perils of the imperial frontier and painstakingly devoted himself to his vocation.

\section{Andrés Marcos Burriel and the Jesuit Vocation for Natural History}

According to Cañizares-Esguerra, Andrés Marcos Burriel was at the center of the most important debates concerning natural history and historiography in eighteenth-century Spain. ${ }^{46}$ Burriel was an active participant in the camp of Spanish intellectuals led by Gregorio Mayans y Siscar (1699-1781) who were concerned about the image of Spain as a cultural and scientific backwater and sought to open the country to the latest developments in history, science, and political-economy circulating throughout Europe. The image of the polymath and cosmopolitan Spanish Jesuit who was versant in the works of Francis Bacon (1561-1626), Isaac Newton (1642-1727), and Gottfried Wilhelm Leibniz (1646-1716), as well as Linnaeus's system of classification, provides a stark contrast to the figure of Venegas. ${ }^{47}$ Benefitting from the mid-century reforms

45 On the spatialization of time in eighteenth-century anthropology, see Johannes Fabian, Time and the Other: How Anthropology Makes it Object (New York: Columbia University Press, 1983), 122.

46 How to Write, 144-45.

47 Indicative of his character and commitment to the advancement of science in Spain, Burriel boldly took on the Spanish Inquisition when it sought to censure a reference to 
underway in the imperial court, the young Jesuit was recognized as a prodigy by eminent figures of the Spanish Enlightenment. Due to his manifest talent and capacity for tireless archival work, Burriel won the patronage of King Fernando VI's (r.1746-59) confessor, the Jesuit Francisco de Rávago y Noriega, a connection to the royal court that would prove advantageous at least until the Society fell out of favor under Carlos III (r.1759-88).

The defining moment of Burriel's career came in 1749 as he was about to embark on a voyage to New Spain where he intended to work as a missionary in California, the fulfillment of a vow he had made to Saint Francis Xavier during a grave illness five years earlier. ${ }^{48}$ Perhaps aware of the talent he was about to lose, Rávago intervened to retain Burriel in Spain with a special commission to undertake an ecclesiastical history of Spain in the archives of Toledo. In his letters to fellow Jesuits, Burriel repeatedly referred to the disappointment of being held back from his vow to work as a missionary in the Californias, for which his prodigious archival work was to serve as a proxy in service of the temporal and spiritual welfare of the Indies. ${ }^{49}$ Burriel's "vehement desire" for the Indies and his vow to the Jesuit proto-apostle to do missionary work on the Spanish-American frontier were redirected to the compiling of information on the affairs of America in order to improve the government of the colonies from the metropole. ${ }^{50}$ The Noticia was in fact the first stage of Burriel's more ambitious plan to mobilize the Society's missionary network and distinct vocation in the service of eighteenth-century natural history.

Burriel's ambitions for modernizing Spanish institutions and improving the government of Spanish America through empirical research place him within

Newton in Jorge Juan's Observaciones astronómicas y fisicas (1748), which the young Jesuit had been commissioned to revise. According to Echánove Tuero, Burriel was entrusted with polishing the style of the otherwise dry scientific treatise and with writing a prologue in order to increase its appeal to readers at home and abroad. Echánove Tuero, La preparación intelectual, 78-79, 98; Víctor Navarro, "Tradition and Scientific Change in Early Modern Spain: The Role of the Jesuits," in Jesuit Science and the Republic of Letters, ed. Mordechai Feingold (Cambridge: The мiт Press, 2003), 331-87, 360-62.

48 Echánove Tuero, La preparación intelectual, 26-29.

49 Andrés Marcos Burriel, Letter to Juan Francisco Tompes, June 3, 1750 (Huntington Library, Pasadena, CA, HM 22237), 1.

$5^{0}$ "Estoy casi de todo persuadido, que la estraña represalía, que se ha hecho de mi, quando ya caminaba despedido al Puerto, destinado a essa Provincia de Mexico, y deseosissimo de sepultarme entre los Californios, o entre los Pimas, ha sido ordenado por Dios, para que el publico de Indias tenga en mi un Agente de pocas fuerzas si; pero de vehemementissimos deseos del bien universal de las Indias." Ibid. 1-2. 
the early Bourbon reforms and Spain's moderate Catholic Enlightenment.. ${ }^{51}$ Burriel's Noticia and his plans for the reform of Spanish science and education suggest that some clergy and religious were not only open to ideas from outside Spain but also were active promoters of these ideas within key institutions. Burriel is representative of the intellectual climate of Spain in the eighteenth century: while rejecting the metaphysical grounds of the New Philosophy, he was a receptive and prolific reader of contemporary science and he wished to contribute to the flow of new ideas throughout Europe. Remaining faithful to his vocation, Burriel used the Empressas as raw material for a work that was contemporary with the work of secular naturalists, ethnographers, and historians in eighteenth-century Europe.

Given the radical changes to Venegas's original work it is surprising that Burriel's name appears nowhere in the Noticia. Though his twentieth-century biographer asserts that Burriel "seemed to have been destined to shine from anonymity," it seems that there were more practical concerns at play than a mere penchant for self-effacement or a show of deference to Venegas. ${ }^{52}$ In a letter to Pedro Ignacio Altamirano, procurator general of the Indies, Burriel acknowledged that, given his detailed account of the Spanish empire's peripheral outposts and his bold recommendations for reforming the colonial government and economy, it would be wise not to use his own name because the $\mathrm{No}$ ticia "deals with delicate matters, and as an employee of the king, I should not speak out, especially as we do not know how they will be received. ${ }^{53}$ Nevertheless, in his letters, and even in his anonymous prologue to the Noticia, Burriel unabashedly distanced himself from his source material and emphasized his own effort to reorganize Venegas's work. Tellingly, in four surviving copies of the Noticia that bear inscriptions from Burriel to friends and colleagues, the

$5^{1} \quad$ Jonathan Israel has placed the culmination of the Catholic Enlightenment, with its delicate balance of providentialism and empiricism, around 1750, precisely the time when Burriel was editing, reorganizing, correcting and rewriting Venegas's daunting manuscript. Radical Enlightenment, 540.

$5^{2}$ Echánove Tuero, La preparación intelectual, 100.

53 "Mi nombre de ninguna manera debe sonar, y con esta condición va a V.R. Es razón que lo luzca solo el Padre Venegas, pues lo principal del trabajo es suyo; no jusguen acá y en México que nos vestimos con sus plumas. Fuera de esto, se tocan cosas bastante delicadas, y es bien que yo, empleado por el Rey, no suene, especialmente mientras no sabemos cómo serán recibidas." Fidel Fita, "Noticia de la California, obra anónima del P. Andrés Marcos Burriel, emprendida en 1750, impresa en 1757 y traducida después en varias lenguas de Europa. Datos inéditos e ilustrativos de su composición, aprobación y edición," Boletín de la Real Academia de la Historia $5^{2}$ (1908): 396-438, here 401. 
Spaniard refers to himself as the "true author" of the work. ${ }^{54}$ Notwithstanding the appearance of Venegas as sole author of the Noticia, it was an ill-kept secret that Burriel was in fact responsible for the final version. For example, in a 1768 work, Bernardo Ibáñez de Echávarri, the former Jesuit missionary turned rabid anti-Jesuit polemicist, declared that all "educated men" knew that Burriel had substantially modified Venegas's original. ${ }^{55}$ Though he criticizes the Noticia as propaganda mandated by the Jesuit superior general in Rome, Ibáñez nevertheless praises Burriel as a "lover of letters" and "of great intelligence."56

In his prologue to the Noticia, Burriel declares that one of the major deficiencies of the Empressas was its excessive length and almost exclusive focus on the missionary endeavors of the Jesuits, which needed to be abridged and updated. ${ }^{57}$ The Spanish Jesuit goes on to declare that his work was more a reconstruction than a simple updating,

It was necessary to begin the work anew, using Father Venegas's text as the primary foundation and adding everything that the most active

54 As in the following inscription to the Professor of Theology at the Jesuit College in Rome: "Al R.P. Eustaquio Josef de Medina, Maestro de Theologia en el Colegio Romano de la Compañia de Jesus ofrece este exemplar de la Noticia de la California su verdadero Autor Andrés Marcos Burriel de la misma Compañía." Ibid., 433. It is telling that the Spanish savant's correspondence requesting information, suggesting reforms and inquiring into the reception of his work does not include any letters to Venegas, In his letter to Juan Francisco Tompes, the Jesuit procurator of California, Burriel disingenuously adds (in passing as a he closes a lengthy explanation on his project for a history of California) that he had not written to Venegas because he did not know if he was still alive. Letter to Juan Francisco Tompes, June 3, 1750 (Huntington Library, Pasadena, CA, HM 22237), 16.

55 “¿Quién ignora tampoco las intercalaciones, y supresiones del mismo Padre Andrés Marcos Burriel en la historia de Californias, escrita por el P. Venegas, y retocada a su modo por dicho Burriel, hombre por otro lado amante de las letras, de gran ingenio; pero que unido por profesión a los intereses de la Compañía, no era dueño de resistirse al despótico imperio del General?" Bernardo Ibañez de Echavarri, Colección general de documentos, tocantes a la persecución, que los regulares de la Compañía suscitaron y siguieron tenázmente por medio de sus jueces conservadores, y ganando algunos ministros seculares desde 1644 hasta 1660 contra el Il.mo y R.mo Sr. Fr. D. Bernardino de Cárdenas, 3 vols. (Madrid: Imprenta Real de la Gaceta, 1768), 1:xlix-l.

56 Ibid.

57 Venegas, Miguel and Andrés Marcos Burriel, Noticia de la California, y de su conquista temporal, y espiritual, hasta el tiempo presente: Sacada de la historia manuscrita, formada en México año de 1739 por el Padre Miguèl Venegas, de la Compañía de Jesús; y de otras noticias, y relaciones antiguas y modernas (Madrid: Imprenta de la Viuda de Manuel Fernández, 1757), 1:xviii. 
diligence could acquire; yet, as the information to be added to the work was individually examined, new defects and omissions became increasingly evident, thus requiring the acquisition of more materials. ${ }^{58}$

Burriel not only reduced the length of Venegas's manuscript, but also reorganized the work and amplified its descriptive-synoptic aspect using primary and secondary sources not available to Venegas. Burriel acknowledges that he is working in a discipline that has undergone a paradigm shift within his century and modestly puts forth his own contribution to the natural history of California as an incomplete but a necessary first step. ${ }^{59}$ The Jesuit refers to the contributions of museums, botanical gardens, and laboratories to the empirical knowledge of the eighteenth century, to which his work was to be a modest addition until more thorough research could be done to satisfy the demands of a sophisticated reading public. ${ }^{60}$

Burriel cites a considerable bibliography of natural histories from the seventeenth and eighteenth centuries including Linnaeus and Mark Catesby (1682-1749), an Englishman who employed the Linnaean system in his book on the flora of Virginia, as well as Joseph François Lafiteau (1681-1746) and Pierre François Xavier de Charlevoix (1682-1761), the immensely influential Jesuit naturalists and ethnographers. Burriel cites Linnaeus's complaint about the lack of reliable information on the flora of the New World, to which the Spanish Jesuit responds by calling on his colleagues in Spain and America to heed the challenge. ${ }^{61}$ Notwithstanding his tacit confirmation of Linnaeus's criticism, Burriel defends the legacy of Spaniards who had contributed to Europe's knowledge of the New World, from Gonzalo Fernández de Oviedo (1478-1557), José de Acosta (1540-160o), and Francisco Hernández (1514-87) to the Relaciones of Jorge Juan (1713-73) and Antonio Ulloa (1716-95), thus securing his place among the long line of historians who have vindicated Spain's scientific heritage against the traditional view of the Iberian peninsula as a backwater of Counter-Reformation Catholicism.

$5^{8}$ "Huvose de emprender de Nuevo todo el trabajo, sirviendo de fondo principal el del Padre Venegas, añadiendo todo lo que pudo adquirir la diligencia más viva; pero el mismo reconocimiento individual de las noticias, que se iban estendiendo, hizo advertir mas por menor nuevas faltas, y huecos, que no era possible enmendar sin nuevos materiales." Ibid., 1:xix.

$59 \quad$ Ibid., $1: 36$.

60 Ibid.

61 Ibid., 1:42-43. 
In his reordering and condensation of Venegas's text, Burriel basically turned the Empressas on its head. Venegas's "mappas historiales" describing the nature and inhabitants of California, relegated to the last part of the Empressas, are transferred to the first book of Noticia and considerably modified to conform to the criteria of the contemporary naturalists that Burriel cites at the beginning of the segment. The first book of the Noticia describes the location, climate, landscape, flora, fauna, and human inhabitants, a strategy that dehistoricizes colonized peoples by presenting a geographic, zoobotani$\mathrm{cal}$, and ethnographic account of the region independent of the diachronic, and inevitably violent, process of colonization. The second segment describes the several failed attempts to colonize the peninsula, beginning with Hernán Cortés's ill-fated plans to conquer California and ending with Isidro de Atondo y Antillón's 1683 expedition accompanied by the Jesuit missionaries Eusebio Kino (1645-1711), Pedro Matías Goñi (1648-1712), and Juan Bautista Copart (1643-1711). The third segment begins with the establishment of permanent missions by Juan María Salvatierra (1648-1717) and Francisco de Píccolo (1654-1729) and ends with the reconquest of the peninsula after the 1734 rebellion that claimed the lives of Fathers Lorenzo Carranco (1695-1734) and Nicolás Tamaral (1687-1734). The providentialism of Venegas's Empressas is only implicitly present in this new structure. In a letter to Juan de Armesto (1713-95), a former missionary in Lower California, Burriel emphasizes the synchronic and synoptic focus of the Noticia as he explains his plans for future natural histories and exhorts his fellow Jesuits, "Let us be the eyes of the world, not only for the spiritual welfare, but also for the temporal, insofar as this does not contradict the former."62 Burriel subtly indicates the transformation of Jesuits' apostolic calling into a vocation for natural history and the creation of a synoptic picture of colonized nature and subjects under a European gaze.

The most controversial addition, which obliged Burriel to prefer anonymity, was the Spanish Jesuit's disquisition on the crown's economic policies in Spanish America. Although Burriel argues for reduced tariffs on mercury in order to promote the extraction of silver, he declares that the true wealth of a country resides in its labor force and manufacturing capacity, which he believes the metropole should develop in New Spain. ${ }^{63}$ Burriel cites Sonora, "one of the richest and at the same time poorest provinces in America and the world," as a specific case of a region that remains underdeveloped because of

62 "Seamos los ojos del mundo, no solo para su bien espiritual, sino para el temporal en quanto no desdiga." Andrés Marcos Burriel, Letter to Juan de Armesto June 1, 176o (Huntington Library, Pasadena, CA, HM 22241), 4.

63 Venegas and Burriel, Noticia, 2:84. 
the continued emphasis on the extraction of precious metals. ${ }^{64}$ Burriel likewise links the Jesuit missions to the project of establishing a port of call in California for trade from the East Indies, which, as Burriel points out, was part of a plan to improve the colonial economy promoted by Julio Alberoni, one of the early Bourbon reformers. ${ }^{65}$ These reforms are proposed as part of a nationalist project to improve the Spanish empire's declining fortunes, for which Jesuit missions were to serve as a first stage, waking the country from its lethargy through an "active" rather "passive" economic policy with respect to other European nations in the Pacific. ${ }^{66}$

Burriel's additions and emendations to the Empressas reveal how the Jesuits' activities on the mission frontier anticipated the Bourbon reforms through the establishment of a civil order and the compiling of natural histories and ethnographies to aid in the political and economic regulation of new territories. ${ }^{67}$ Burriel was directly involved in the mid-century "reformismo de fronteras" through his own historiographic efforts as well as through his support of Ulloa and Juan y Santacilia's work. ${ }^{68}$ Burriel's letter to Juan Francisco Tompes (1701-?), ${ }^{69}$ the Jesuit procurator of California, is imbued with the Enlightenment spirit of correcting the errors of inherited knowledge, ignorance, and

64 "De Sonora puede decirse, que es una de las Provincias mas ricas, y mas pobres a un mismo tiempo de la America, y del Mundo." Ibid., 2:79. Under the Bourbon reforms carried out under Carlos III (r.1759-88), colonial administrators would focus on maximizing the profit of silver production. This economic policy was carried out with notoriously ironfisted measures by the visitor general of New Spain, José de Gálvez (1720-87), who also carried out the expulsion of the Society of Jesus in 1767. John Tutino, Making a New World: Founding Capitalism in the Bajio and Spanish North America (Durham: Duke University Press, 2011), 229-6o.

65 Venegas and Burriel, Noticia, 2:288. According to John Lynch, "The Alberoni quinquennium (1715-19) was not exactly a stage in Bourbon reform, yet he could claim some successes," among which Lynch includes the improvement of the Spanish navy and the reform of commerce in the Indies. Bourbon Spain, 1700-1808 (New York: Blackwell, 1989), 78.

66 "para que la España antigua, despertando de su letargo, entablasse Comercio activo, y no sufriesse el puro pasivo en Europa." Venegas and Burriel, Noticia, 2:292-93.

67 Weber, Bárbaros, 102-11.

68 Manuel Lucena Giraldo, "El reformismo de frontera," in El reformismo borbónico: Una visión interdisciplinar, ed. Agustín Guimerá (Madrid: Alianza Editorial, 1996), 265-76. Lucena Giraldo explains that from $175^{\circ}$ the Bourbon state increasingly took control of overseeing the new impetus of territorial exploration and expansion with an emphasis on social and political control.

69 Gutiérrez-Casillas, Diccionario Bio-bibliográfico, 575-76. Gutiérrez-Casillas does not register the death of Tompes. The last year given for Tompes in the Diccionario Biobibliográfico is 1748 , when he served as procurator of California. 
superstition in order to, in the words of Burriel, "enlighten the modern state of the Indies."70 In addition to his proposed work on California, Burriel also detailed his plans to write a natural history of all of New Spain in which he would put to use the Jesuit missionary network and educational apparatus to map the colonial frontier, catalogue flora and fauna, and provide ethnographic data on the Amerindians of the viceroyalty. Burriel mentions the difficulties of governing the viceroyalties in a vacuum of reliable information and asks his interlocutor: "Is this not a necessary undertaking for the spiritual and temporal government of America?"71

In his correspondence, as with his work on California, Burriel subordinates the Jesuits' apostolic mission to the end of efficient government through the order's role as collector, producer, and disseminator of knowledge. In hagiographic writing, such as Venegas's Empressas, evangelization and acculturation on the colonial frontier were portrayed as the fulfillment of the ideal Jesuit missionary's apostolic-ascetic vocation and as the providential justification of Spanish sovereignty. As portrayed in Burriel's letters and the Noticia, however, Jesuit missions increasingly became the means, or the peripheral tentacles, of a global knowledge-producing network at the service of science and colonial administration.

Burriel's reformulation of the Empressas was in fact only one facet of his ambitious plans for reforming education and science in Spain and Spanish America, a reform that the Society would be uniquely equipped to undertake and from which the order would ultimately reap benefits. The Spaniard asserted that the Noticia would serve as an example to instruct all Jesuit missionaries in what information to gather and remit to their superiors for the benefit of knowledge and efficient administration of the colonies. ${ }^{72}$ Burriel was

70 "[...] ilustrar el estado moderno de las Indias." Letter to Juan Francisco Tompes, June 3, 1750 (Huntington Library, Pasadena, CA, HM 22237), 2.

71 "Por otro lado, no es esta una obra necesaria para el gobierno spiritual y temporal de la América." Ibid., 12.

72 Ibid., 4. Burriel's intention to publish the Noticia as a template to be corrected and completed by missionaries who had direct knowledge of California was fulfilled by the exiled Jesuits Miguel del Barco (1706-90) and Lucas Ventura (1727-93), who had served in the peninsula and wrote reports to supplement the Spaniard's work. In fact, copies of the Noticia were found in the modest libraries of the California missions when they were catalogued after the expulsion. Miguel León-Portilla, "Estudio preliminar," in Miguel del Barco, Historia natural y crónica de la antigua California (México: Universidad Autónoma Nacional de México, 1973), v-lxiii; Bernabéu Albert, Expulsados del infierno, 126-46; Michael Mathes, "Oasis culturales en la Antigua California: Las bibliotecas de las misiones de Baja California en 1773," Estudios de historia novohispana 10, no. 10 (1991): 369-442. 
aware, however, that this example would have to accompany reforms to Spain's educational institutions in general and to the formation of Jesuit novitiates in particular. Displaying the nationalist spirit of these proposed reforms, Burriel laments that the lack of interest in the type of natural history he wished to write "has sufficed to confirm the Spanish as barbarous and brutish among the nations of Europe." ${ }^{\prime 3}$ The Spanish Jesuit argued that this lack of interest was due to educational institutions that permitted students to graduate in their formative years ("edad de aprehender") without the fundamentals for understanding experimental physics, natural history, and geography. ${ }^{74}$ Furthermore, few students were capable of competently reading maps or performing basic mathematical calculations. This, according to Burriel, had led to an adult reading public of religious and laymen alike "without the least taste for critique and discernment in judging what they read or see, without the love of ancient books and despising the modern works on the aforementioned topics, or without curiosity." 75

Burriel argued that Jesuit missionaries stationed around the globe were uniquely positioned to add to the Enlightenment archive of natural histories, yet this potential remained untapped. In a partial indictment of the order's own educational apparatus, the Spaniard asserted that many missionaries were not entirely to blame for not fulfilling their potential: "From such an education one would not expect great advances either here or over there, and thus many are not to blame for not being what they should, for it is not in their power to be any better."76 Burriel insisted that there were "many capable Spaniards and foreigners" in New Spain but that they lacked proper books and instruments, and even when capable minds set out to scientifically observe and record the nature and inhabitants of the colonial frontiers they lacked opportunities to publish their work and win the recognition they deserved. ${ }^{77}$ Here and elsewhere, Burriel betrays his single minded focus on the missionary as an empirical observer who must record or collect anything of scientific interest on the colonial periphery. By not fulfilling this function, argued Burriel,

73 “...] ha bastado a acreditar a los Españoles de bárbaros, y brutales entre las Naciones de Europa." Letter to Tompes, June 3, 1750 (Huntington Library, Pasadena CA, HM 22245) 8.

74 Ibid.

75 " [...] sin gustillo de Crítica, y discernimiento para jusgar de lo que leen, o de lo que ven, sin amor a los Libros antiguos, y con desprecio de los modernos, sin curiosidad." Ibid., 9 .

76 "De educación semejante no deben pedirse grandes adelantamientos ni acá ni allá, y por tanto muchos no son culpables en no ser, como debieran, porque no está en su mano ser mejores." Ibid.

“[...] muchos españoles y extrangeros hábiles." Ibid. 
his Jesuit confrères were doing a disservice to the progress of knowledge, the Spanish nation, and the Society of Jesus.

Although in his letter to Tompes Burriel mentions the addition of edifying letters on the California missionaries whose lives were not included in the Empressas, this is overshadowed by his desire to reach a wider reading public in Europe. As he stated in his letter, Burriel hoped to gather new information in order to transform Venegas's manuscript into a "complete and exact history with all the care and attention that the people of good taste in this day and age desire."78 The Spanish Jesuit specifies what kind of exact and complete natural history the people of "good taste" expect, only briefly mentioning missionary biographies. Indeed, in proposing a multi-volume series of Edifying Letters from New Spain after the popular French model, Burriel remarks that these must include subjects to stoke the curiosity of readers who would otherwise shun a purely hagiographic work:

It is certain that by God's grace there are sufficient materials so that together with the relations from all the provinces we may produce something of quality and make known what the Society is doing. It is necessary that from here on we shall not make any omissions, and that matters of curiosity be added to those of edification in order to appeal to all types of reader, which will not be accomplished without this bait, otherwise only our lay sisters [beatas] will read the relations. ${ }^{79}$

Burriel dismissively refers to the readership of Jesuit Edifying Letters as "nuestras beatas," that is pious women devotees or nuns under the spiritual guidance of the Jesuits. His feminization of this reading public is telling not only as a reminder of the hyper-masculine ascetic culture of the Jesuits but also as representative of the Enlightenment association of scientific objectivity and rigor with the masculine, ascetic subject.

While Burriel's ambitions may be attributed to the individual enthusiasm of one youthful, talented and well-connected member of the Society without

78 "He recorrido los mismos Libros que cita el Padre Venegas, y últimamente he reconocido, que no hay materiales bastantes, para hacer una Historia cumplida, y exacta con todos aquellos primores y delicadezas que hoy desea la gente de buen gusto." Ibid., 1.

79 "Es cierto que por la gracia de Dios hay materiales para que juntas las Relaciones de todas las Provincias se haga una cosa Buena, y se de a conocer bien lo que trabaja la compañía. Solo falta que no haya omission en adelante, y que a las cosas de edificación se añadan las de curiosidad de modo que aficionen a toda suerte de lectores, lo no se logrará sino con este cebo, de otro modo solo leerán las relaciones nuestras Beatas." Ibid., 13. 
resonance among his confrères, the reception of his work demonstrates that he had many like-minded colleagues. After the completion of the Noticia, the first step in his project for reform, Burriel even more emphatically pushed his proposals in letters to his novo-Hispanic counterparts. In this correspondence, we can even more clearly see how in the eyes of the Jesuits the order's ascetic ideal and organizational structure lent itself to the work of natural history in the age of Enlightenment, increasingly becoming an end in itself. Balthasar, a former visitor general of missions and provincial of New Spain, praised the "terse eloquence" of Burriel's Noticia and confessed to the Spaniard that if the Empressas "had been made public in Father Venegas's style, without the addition of the select and invaluable information that Your Reverence wove into the narrative, it would have gained limited acceptance." 80 Referring to Venegas's rhetoric, the elder Jesuit lamented with frankness, "this is the style commonly used in these parts where we lack many resources that might ennoble our writings." ${ }^{81}$

Despite his praise for the Noticia, Balthasar noted that Burriel had privileged natural history over missionary biography, and encouraged Burriel to include biographies of Salvatierra, Piccolo, and Juan de Ugarte (1662-1730) in the second edition of his work, which he admitted would never be read if they were published as independent edifying letters. ${ }^{82}$ In the minds of these Jesuits, the life of the ideal apostle had become a supplement to the principal object of the Noticia, which was to provide an accurate geographic, natural, ethnographic, and historical account of Lower California. This is not to say, however, that the ascetic-apostolic ideal was renounced; on the contrary, the disciplined gaze of the missionary became that of the critical researcher gathering and scrutinizing data in the field or the archive.

The academic formation of these missionary-researchers was likewise a concern for Balthasar, who understood along with Burriel the consequences for the future of the Society if the order did not keep up with the epistemic shift it had helped to bring about. Balthasar expresses his disappointment with a novitiate to whom he had commissioned the composition of a history of California and who, according to the former provincial, could not accomplish

$80 \quad$ "...] y desde luego si hubieran salido al público en estilo natural del padre Venegas sin el aumentado de las noticias selectas y apreciables con que Vuestra reverencia entretejió la relación hubieran logrado corta accepción" Juan Antonio Balthasar, Letter to Andrés Marcos Burriel, February 24, 1759 (Huntington Library, Pasadena, CA, HM 22240), 1.

81 " [...] esto es el estilo que por lo común se usa por acá donde se carece de muchas noticias que pudieran ennoblecer los escritos." Ibid., 2.

82 Ibid., 5 . 
in seven years what Burriel could write in fifteen days. ${ }^{83}$ Just as his Spanish counterpart, Balthasar attributed this inadequacy to a slackening in Jesuit education and a lack of interest in tapping the potential of the order's missionary outposts and communication network. ${ }^{84}$ Offering his own ambitious reform, Balthasar proposed that the order properly school missionaries in navigation and mapmaking, and furthermore suggested that each province should have two "exploring fathers" ("padres descubridores") solely dedicated to the activity of collecting, surveying, and mapping the colonial frontiers, without any evangelical responsibilities. ${ }^{85}$ In the relegation of evangelical labor this scheme did not abandon the order's ascetic ideal, but rather the scientific and ethnographic mission itself became an apostolic-ascetic exercise, exposing the missionary-fieldworker, or "padre descubridor," to the same discipline, risks, and privations in the service of religion, government, and science.

\section{Conclusion}

There is a great deal of historical irony in these discussions of ambitious projects and reforms, for at the time of these personal exchanges the secularscientific world picture that the Jesuits had helped establish and continued to transform was turning against the order in what would prove to be its most embattled moment. In his letter to Burriel, Balthasar alludes to the order's tribulations when he mentions the obstacles to funding his proposals: "I well know that asking for resources to pay for ships, soldiers, and sailors is political heresy at this time when the affairs of Paraguay are boiling over."86 Balthasar, of course, was referring to the loss of the prized Jesuit reducciones in Paraguay after the $175^{\circ}$ Tratado de Límites between Spain and Portugal, an event directly linked to the expulsion of the order from Portugal in $1758 .^{87}$ The Paraguayan affair triggered a chain of events in Europe and the Americas that

\footnotetext{
83 Ibid., 3 .

84 Ibid., 6 .

85 Ibid., 7 .

86 " [...] bien sé que pedir dependencia del barco, soldados y marineros, y gasto es pedir una heregia política en tiempo cuando están tan calientes los cuentos del Paraguay." Ibid., 8.

87 In order to control contraband trade in Colônia do Sacramento, Spain negotiated to take over the enclave from Portugal in exchange for lands that included seven of the Jesuits' Guaraní reducciones. The Jesuits' impassioned and polemic efforts to stop the treaty were later used against them as evidence of their hostility to the interests of the Spanish crown. When the Guaraníes rebelled against Spanish and Portuguese attempts to resettle them, the Jesuits were blamed for instigating the uprising. Lynch, Bourbon Spain, 179-82.
} 
would eventually lead to the expulsion of the order from all Spanish territories in 1767 and its suppression by papal breve in $1773 .{ }^{88}$ Neither Burriel (d.1762) nor Balthasar (d.1763) would live to see these events unfold.

As he demonstrated in his Noticia and his correspondence with his fellow Jesuits, Burriel believed that the Jesuits' dual vocation as "apostles and men of learning" was most aptly embodied in the production of natural histories from Spain's overseas territories, and would best serve the order against its critics. Although he diminished Venegas's providential rhetoric, Burriel nevertheless understood the apostolic-ascetic vocation of the Jesuits as the basis for the epistemological shift in eighteenth-century natural history, and he hoped that the order could use its corporate identity and global network to reform Spanish-American colonial government and improve the standing of the Society of Jesus throughout Europe. Though Burriel participated in the debates that generated what Cañizares-Esguerra has termed a "patriotic epistemology," this nationalist-revisionist project was predicated on the Society's ascetic ideal and organizational structure. Just as Burriel's work was translated and widely disseminated throughout Europe, so too were the Jesuits' methods of framing the colonial frontier in the discourse of natural history. Venegas's and Burriel's works require us to view the Jesuits as both precursors and contemporaries to Enlightenment natural history, geography, and ethnography, a perspective that has been skewed by the order's fate in the second half of the eighteenth century.

88 William V. Bangert, A History of the Society of Jesus (St. Louis, Mo: Institute of Jesuit Sources, 1986), 363-402. 